\title{
Tathagata Buddha Songs: Buddhism as Religion and Cultural-Resistance Among Dalit Women Singers of Uttar Pradesh
}

\author{
Kalyani Kalyani'
}

\begin{abstract}
This paper intends to understand music as a form of cultural expression that has enabled mobility to Dalit-Bahujan and their cultural production. This cultural production can be seen in the form of popular songs that are widely circulated among Dalits and is part of their religion, identity, as well as a cultural assertion. Tathagata Buddha songs, which this paper studies, has been specifically enabling for Dalit women as it gives them not only a sense of religiosity but it also opens them to the possibility of rationalizing their beliefs and practices. The paper will bring up an ethnographic account of some of these Dalit women singers and look into some of their composition and songs that have a specific invocation to Gautam Buddha and of political icons like Babasaheb Ambedkar, whom they revere. A study of Tathagata Buddha songs and Bhimgeet can provide an insight into how music has departed from being just an aesthetic sensibility to a language of resistance against the oppressive caste order. The paper also explores the material dimension of Tathagata Buddha songs understanding its circulation, production, and platforms through which these are popularized.
\end{abstract}

\section{Keywords}

Tathagata Buddha, songs, Dalit, resistance, women, Bhimgeet.

\section{Introduction}

Cultural-resistance is witnessed particularly among Dalit women in various popular forms and practices. The emergence of Tathagata Buddha songs $^{1}$ can be seen as a form of resistance because its spread, popularity, and acceptance are

\footnotetext{
'Ph.D. Scholar, Centre for the Study of Social Systems, Jawaharlal Nehru University, New Delhi E-mail: kalyani.official.5@gmail.com
} 
marked in a particular moment of history that is the conversion of Dalits into the fold of Buddhism on October 14, 1956. ${ }^{2}$ The conversion by Dr. B. R. Ambedkar made Buddhist philosophy accessible to the masses not just with the sense of religiosity but as a belief of social emancipation. Omvedt (2003) has argued that for Dr. Ambedkar religion was close to the Durkheimian perspective on religion that is something which is 'a binding force for social relationship' (p.260). The act of taking up Buddhism for Dr. Ambedkar was not just a religious or a moral goal, but it was deeply rooted in restoring human dignity. The emergence of Buddhism particularly post-conversion witnessed a new cultural wave, in which musical practices like Tathagata Buddha songs gained widespread mass appeal.

Tathagata Buddha songs refer to a set of singing practices, hymns, and other musical performative dimension that is particularly dedicated to Buddha, his preaching and the sense of emancipation ${ }^{3}$ that the emergence of Buddhism imbues. The widespread circulation of Tathagata Buddha songs is particularly popular among Dalit women who are active producers as well as the recipients of these songs. This paper seeks to understand the meanings that Tathagata Buddha songs have in the lives of Dalit women and how their everyday life-world is influenced by these songs. Further, the paper explores the different dimensions of Tathagata Buddha by looking into its form, content, and practice. It traces the emergence of these songs and earlier forms of cultural resistance that were witnessed during the Bhakti movement. It also engages with some of the Tathagata Buddha songs that are popular in North India and the influence these have on the life-worlds of its followers, particularly the Dalit women.

\section{Musical practices in Uttar Pradesh: Emergence of Tathagata Buddha Songs}

Music has been an important cultural aspect that has been the voice of culturalresistance and assertion. While there have been different genres of music that have been popular across India, in Uttar Pradesh the popular genres of music are Ragini, Birha, Parody music, Alha music, and so on. The association of these genres has a deeply entrenched association with Dalit lives. For instance, the singing of Birha is closely associated with Dalits' everyday lives. Jassal (2012) has discussed the Birha folk singing practices through which Dalit women, in particular, have expressed themselves. Most of these genres of music have constantly been reworked with the socio-political movement. For instance, a very popular Dalit singer in North India, Kishor Kumar Pagla, is a very well-known Birha singer. Similarly, the Alha genre of music, popular in the regions of Kannauj, has also engaged with the production

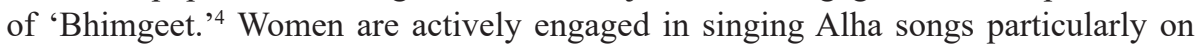
occasions like marriage. With the socio-political-cultural revolution, the composition and style of singing Alha songs has seen considerable changes. For instance, Seema Azad is a famous Alha singer who has sung Bhimgeet and Tathagata Buddha songs in Alha style. ${ }^{5}$

The practice of Tathagata Buddha songs is particularly popular among converted Buddhists, who have adopted Navayana Buddhism ${ }^{6}$ as their religion. Many of the songs that are produced are largely reworked in the musical genres which are popular in Uttar Pradesh. These songs are also chanted as part of Katha Pathan, a cultural performance in which the life and philosophy of Buddha are read out in public visibility. One of 
the very famous works of this Katha Pathan is done by Dr. Angane Lal in his popular collection titled Adivansh Katha. The 'practice' of Katha Pathan begins with rituals such as placing peepal (sacred Fig) leaves and other Buddhist artefacts at the prayer dais or platform.

Tathagata Buddha songs and its production in the regions of North India largely reflect the contestations that these new-forms of popular music are creating along with the existing forms of popular music. With socio-political awareness, Dalit-Bahujan people are increasingly taking up Ambedkarite practices and Buddhist tradition. The growing popularity of Tathagata Buddha songs reflects the widespread influence and reach of Dr. Ambedkar's conversion ideology in Uttar Pradesh.

\section{Locating the history of Cultural-Resistance}

Bhakti (devotion) movement ${ }^{7}$ has been an important vantage point to understand socio-cultural-resistance. The emergence and growth of the Bhakti movement can be traced from medieval period saints Chokamela to Eknath, Tukaram, and Kabir. Each of these strands of Bhakti tradition had witnessed different kinds of musical traditions and practices. These included the singing of Kabir's Bijak (compilation of verses), Chokamela's abhangas (devotional poetry), Tukaram's Kirtan (devotional songs), etc. These Bhakti traditions had a unique influence on women in particular.

The Bhakti movement has given different meanings, particularly to women in terms of how they perceived Bhakti tradition. Karwe (1998) while trying to explore the concept of sacred, has looked into what Lord Vithoba ${ }^{8}$ meant for the women in Pandharpur. Vithoba is addressed with different familial relationships like mother, father, friend, lover, and so on. There is a degree of closeness with which he associated. Within Bhakti tradition, is a stage of devotion known as 'Madhur Bhakti' in which devotees associate themselves with Rukmini and look upon their Lord Vithoba with the affection and devotion associated with Radha-Krishna kind of relationship. It thus throws light on the relationship the people of Pandharpur have with Lord Vithoba, that of love and reverence.

However, Dhere (2011) has argued that such reconstruction of religious tradition and practices surrounding the emergence of Vitthala or Vithoba as Vaishnava deity happened later during the early medieval period during the Wakari movement. ${ }^{10}$ In his translated work by Dr. Anne Feldhaus, Dhere has argued that a study of musical practices ${ }^{11}$ shows that Vitthal was 'Buddha' and that calling him Vishnu avatar (reincarnate) or Krishna was to 'vedicize' (Vaidikikaran) Vitthal through ritual prescription and Sanskrit hymns. Notwithstanding the debate on the origin of Vithobha or Vitthal, it is also important to look upon how the Bhakti tradition and its musical practices were some of the early forms in which Hindu casteist traditions and practices were challenged.

Chokhamela, belonging to the Mahar community was an important Bhakti saint of the thirteenth-fourteenth century. His devotional songs known as Abhangas discussed the concept of untouchability, besides discussing the piety of a devotee or Bhakta. Zelliot (1980) has argued that the discussion on Chokemela's abhangas often ignores the untouchability dimension that he had explicitly despised in his songs. Ranade (1961) says that Chokemela's abhanga by discussing the practice of untouchability gives legitimacy to modern ideas of justice. Similarly, Eknath's Bharuds (songs) also reflects on the everyday conversation in village life. These compositions describe the 
position of Mahars in Maharashtra, thereby reflecting upon the life of Dalits as it existed then.

Other musical traditions in Bhakti can be drawn from Saint Tukaram's emphasis on kirtan as a means of liberation and attainment of divine bliss (Manuel, 2001). Kirtan as a genre of devotional musical tradition also has an important place among Chaitanya $^{12}$ followers. Another response to the oppressive Brahminical caste structure was questioned in Kabir's poetry, ${ }^{13}$ known as Bijak. Hess (1983) while looking into Bijak, which is also the sacred text among Kabirpanthis or his followers, has argued about the 'upside-down language' used. The poems are 'absurd, paradoxical, crazy, impenetrable, and yet they purport to be meaningful' (Ibid, p.314). It is significant to understand here that the 'upside-down language' structure provides an alternative way to question the existing social order. Hess has argued that this cryptic tradition is also found in the Hindu and Buddhist 'Siddha' tradition in the twelfth century. For Kabir, the usage of 'upside-down language' was an allegory to departure from the existing order, and reaching to newer possible meanings. Thus, the significance of poetry to develop an alternative meaning was possible as we see in Kabir's couplets. Such construction of alternative meaning opened newer possibilities of questioning prevailing caste structures.

\section{Buddhism in Popular Culture}

Buddhism has a rich history of art and architecture. These art forms are witnessed in rock-cut halls, Chaityas (prayer hall or shrines), and Viharas (monasteries). Art has an important function of giving identity and is thus, an important part of the culture. The emergence of Navayana Buddhism has its sense of aesthetics that has renounced the existence and worship of any form of God. Thus, the emergence of Navayana Buddhism has witnessed a newer sense of aesthetics that has floated across DalitBahujan culture. Tartakov (2012) looks into Navayana Buddhism as having a much clearer vision than Theravada Buddhism and is simpler in practice. The Navayana tradition has seen significant changes from the earlier forms. For instance, in a conventional Navayana practice, a pair of Ambedkar and Sakyamuni statues would be erected. Dr. Ambedkar came to be known as Maitreya Ambedkar. The changes in the interpretation of the imagery of Buddha are also seen. The re-interpretation of Buddhist imagery will engage with the disappearance of Buddhism and with its reemergence in Dalits' practice of Buddhism.

Buddhist culture is being made to seep in the Dalit community by way of wide circulation of popular music forms, distribution of Buddhist pamphlets, prayer books (Buddha-charini), Buddha images, artefacts, etc. This new popular image of Buddha is different from the traditional representation that had a more lavish and luxurious representation. For instance, Tartkov (Ibid) discusses that most of these contemporary Bodhisattva imageries are followed with the representation of Dr. Ambedkar which is simpler and more realistic. It is denied any superficial form of decoration. Such changes in the representation can be termed as 'revolutionary' as these changes have been instrumental in re-shaping the Dalit community's psychology towards their orientation to social and material life.

Buddhism in popular music has been accepted by people not as a monastic order but as a form that largely reflects their cultural thought process and their resistance to the traditional practices of caste-based humiliation and exclusion that Dalits have been 
subjected to. The paper will further look into Tathagata Buddhist songs in their form and content and discuss the reception of these songs by Dalit women in particular and what these songs mean to them.

\section{Music as Resistance}

Music and its performance are significant in spreading a message, which would otherwise have not been accessible. Since it involves the element of 'popularity' it is widely accepted. Friedman (2013) talks about the poem 'We shall overcome' which became the emblematic poetry of the civil rights movement led by Martin Luther King, Jr. He said in one of his speeches that he is not going to stop singing

We shall overcome because I know that truth crushed to the earth shall rise again. I am not going to stop singing 'We shall overcome' because I know one day the God of the universe will say to those who won't listen to him, I am not a playboy.

Don't play with me. I will arise and break the backbone of your power'. I am not going to stop singing, 'We shall overcome' because 'mine eyes have seen the glory of the coming of the Lord. He's trampling out the vintage where the grapes of wrath are stored. Glory hallelujah, his truth is marching on. ${ }^{14}$

Thus, one finds that We Shall Overcome was not only the song but within that song was a deeply entrenched idea that was imbued.

Similarly, there are other songs like We Are the Champions in the 1970s to mark the gay rights movement. The sense of resistance in music was not just about its lyrics but it was also reflected in its performative dimension. Woldu (2013) has looked into the performative dimension of rap music and how the feminine rap music through its exquisite dressing brought wreck to the dominance in hip hop. For instance, Queen Latifah, who was the first rap dive made her presence felt in the male-dominant rap through the 'aggressive style.'

Discussing the genre of rap, Beighey (2006) has also argued that political rap has become a form of resistance through which the Black community has shed-off their alienation. It is a response to the sub-cultural alienation that they face within the larger mainstream culture. The rap form has a deliberate use of language and expression through which it has tried to call attention to their exploitative historical experiences. Beighey's study has thematically looked into several forms of exploitation like criminal justice discrimination, racial genocide conspiracy, lost economic opportunity, educational bias, mass media misrepresentation, police brutality, health care inequality, and so on. Against this backdrop, rap music has become an important instrument to question and resist mainstream media stereotyping. For instance, Beighey in her work has discussed how within the Rap music genre black men are represented as having paramilitary outfits which yields them powerful symbol as well as it reworks on the kind of racial stratification (Ibid).

Thus, music as an art form has constantly tried to capture the spirit of resistance, as it can be traced from Bhakti tradition to contemporary resistance practices of groups like Kabir Kala Manch (Kabir art platform) or Youth for Buddhist India. Such a form of resistance was particularly popular among the colored in America, with the emergence of the Hip-Hop 'subculture.' For instance, Bell Hooks (1995) has argued: 'art constitutes one of the rare locations where acts of transcendence can take place and have a wide-ranging transformative impact' (p. 8). She argues that 'there is a need to understand and appreciate the work of a black artist as it is since it carries with it a sense 
of culture that is unique to it. The production of art forms is an essential component of resistance during black liberation struggles. However, such production of an art form is often debased and appropriated, which makes it lose its meaning.' Hooks (Ibid) has presented her apprehension for the commodification of 'blackness' and black culture, which is distancing it from its real essence of struggle and resistance. Firth (2007) has argued on similar lines while discussing popular music. While discussing features of popular music, one of the distinguishing features he refers to is the sense of 'possession' that popular music enjoys. It belongs to an identity and a culture. It has the potential to create a sense of identity that people associate with.

\section{The Emergence of Tathagata Buddha Songs}

The emergence of Tathagata Buddha songs in Navayana Buddhism gained popularity, particularly post-independence, following the Dalit conversion led by Dr. Ambedkar on October 14, 1956. The uniqueness of Tathagata Buddha songs as popular among Navayana Buddhist lies in its 'practice.' Unlike traditional devotional songs in other communities, Tathagata Buddha songs are not just for spiritual quest, but contain a deeper social message of equality and fraternity drawn from Buddha's life. Many of these songs are in the form of chants of three lines (trisarana). For example,

Buddham Sharnam Gachami (I go to the Buddha for refuge)

Dhamam Sharnam Gachami (I go to Dhamma for refuge)

Sangham Sharam Gachami (I go to the Sangha for refuge)

It is significant to discuss here that in most of these songs of Navayana Buddhism, Gautam Buddha is referred to as 'Tathagata' and not as 'Lord' Buddha. Joshi (1969) has discussed that the epithet 'Tathagata' has its root in two words 'Tatha+Agata'15 which means the arrival of the enlightened one or the one who has attained Nibbana. The term 'Tathagata' traces its roots from Pali rather than the Brahminical notion that considered Buddha as god or 'avatar' of Lord Vishnu. Thus, the very term 'Tathagata Buddha' song is distancing itself from any of the mythical origins attributed to Brahminism.

Many of the Bhakti songs can be referred to as 'Pop Bhajan', which is discussed by Manuel (2001, p. 109). These 'Pop Bhajan' songs of the 1980s were associated with vocalists like Anup Jalota and Pankaj Udhas. They were like contemporaries of renowned ghazal singers, whose styles were adapted in devotional songs. Their style became very popular and thus got highly commercialized over a period of time as a result of wide scale marketing. If one looks into the new popular form of music that is emerging particularly among the Bahujan community, these 'pop-bhajans' are getting replaced with Bhimgeet and Tathagata Buddha songs. These new popular forms are rich with historical and cultural narrative. The viewership of these songs is rising and they are actively entering popular imagination.

When one particularly looks into Tathagata Buddha songs, they are not the traditional protest songs, but are largely devotional in nature centered on the practices of Navayana Buddhism. Their historical narrative responds against caste oppression and the contribution of Babasaheb. Most of these songs are widely circulated on many of the Youtube channels such as Samata Awaz, Awaz India, Bahujan TV, etc and social media too. In most songs, the images of Buddha are invariably portrayed along with those of Dr. Ambedkar. This iconographic representation of Buddha and Dr. Ambedkar 
reflects the significant cultural change in the presentation of 'Pop Bhajans' of the Dalit-Bahujan community in the form of Tathagata Buddha songs and Bhimgeet.

These songs, especially their form, appear similar to 'Pop Bhajan' of the 1980s that Manuel had discussed in his work. Most of these songs that circulate in western U.P. have musical adaptations from mainstream Bollywood songs or mainstream Bhajans and Aarti. ${ }^{16}$ Manuel (2001) has argued that such adaptations are done largely to popularize and spread circulation. However, besides commercial logic, it is also driven by the 'creative resignification process' (Ibid, p. 140). This 'resignification' can largely be understood in terms of the changes that are done in the content of Tathagata Buddha songs. For instance, if the mainstream Bhajan has an Aarti dedicated to a god, these songs will have a similar form but the lyrics will be about Buddha and his Dhamma. Such adaptations enable a widespread circulation of these songs while ensuring that it largely represents the culture and practices of the Dalit-Bahujan communities besides giving them a distinct 'social' space.

The emergence of 'social' space has been particularly enabling for the Dalits as it has given them a cultural alternative by 'de-caste(ing)' themselves from the Hindu social order (Wankhade, 2008, p. 55). The emergence of Tathagata Buddha songs has thus given a cultural alternative to Dalits to re-assert their identity in a manner that has enabled them to transgress their 'fixed' identity under the Hindu caste order. The emergence of a new cultural space is relevant, as it has allowed Dalits to come out of their traditional roles and identity, and take up newer roles and meanings that have empowered and recognized them.

\section{Meanings of Tathagata Buddha songs}

Tathagata Buddha songs and Bhimgeet thus have given a sense of emancipation for many of the Dalit women singers like Dharmacharni Pragya Kirti, Shweta Sakhya, among others. These new adapted forms of popular music have literally changed the underlying tenor of traditional Bhakti songs. By reworking on lyrics of those songs which largely drew from Hindu mythology, the Dalit neo-Buddhists have used the Tathagat Buddha songs as an expression of resistance by imbuing in them historical and social messages.

Many of these Tathagata Buddha songs sung by Navayana Buddhists not only have invocations of Buddha but also of other social reformers who are revered within the Dalit community. Even the reverence shown towards Tathagata Buddha is with specific reference to the Brahminical social order that Buddha had questioned towards the fourth century BCE. The songs have specific reference to social exclusion which Dalit community has faced and the sense of emancipation that Tathagata Buddha songs often imbibe. The songs often re-work the content that highlight the Buddhist philosophy and discuss global goodness. One of the popular songs has the following lyrics.

Buddha ne Sansar jagaya (Buddha has awakened the world)

Samata ka hai Phool Khilya (Enabled the blooming of the flower of equality)

Hum to tere gyan ko apnye hai (We have embraced your teaching)

Hum diwane, hum diwane, (We have fallen in love with you)

Hum diwane, Hai tere.. (*2) (We have fallen in love with you) *2

Tumhare bina jag suna pada hai (Without you the world is deserted)

Aao pyare Gautam tera asara hai (Oh affectionate Gautam we seek your support) 
Ye araz thukra mat dena (Please don't reject our request)

Akar tum gyan batna (Come and enlighten us)

Hum to iss duniyake bahut satye hai (We have been persecuted in this world)

Hum diwane, hum diwane (We have fallen in love with you)

Hum diwane hai tere. (We have fallen in love with you) ${ }^{17}$

The songs convey a deep sense of reverence for Buddha and his teachings are particularly invoked in most of them. Many of these songs have words like karuna (compassion), pragya (wisdom), sheel (modesty), which are propounded as desirable traits of human behaviour in Buddhist philosophy. The songs are in the existing form of 'pop bhajan' and have been re-worded into Buddha Bhajans (hymns) with parallels drawn from mainstream religious literature with titles like 'Buddha Amritwani', and 'Buddha Stuti.' Many of these new popular songs also use the music and form of mainstream Bollywood songs to ensure that they become popular and widely circulated. The viewership of these songs has been rising over a while with support of social media platforms like YouTube, WhatsApp, mobile music, and popular music websites like Ganna.com, Savan Music, etc.

The Buddhist songs are more than being purely spiritual nature. They embody a worldview that has an agenda of social justice, equality, and compassion. Bradley and Bhatewara (2013) term this Navayana Buddhist tradition as 'practical spirituality' by which the humanist aspect of Buddhism is placed at the centre of Buddhist philosophy instead of abstract or other-worldly religious philosophy. Most of the songs popular as 'Buddhacharni', 'Vandana Sutra Pathan, or 'Buddha Vandana' have been reinvented in a way that accommodates Navayana Buddhist philosophy and tradition. The production of such songs is actively taken up by organizations like Karuna Trust, The Triratna Buddhist Community, Youth for Buddhist India, ${ }^{18}$ among others. The thrust of Buddhism in these platforms is largely development-oriented. The aim of one such organization Youth for Buddhist India (YFBI) is to spread Buddhism and social consciousness among Dalits. Baudhcharya Shanti Swaroop Baudh, who is the founder of YFBI says that through cultural and musical performances, YFBI aims to spread the rational and humanist approach among the youth of the country.

In North India, particularly Uttar Pradesh, many of these songs are circulated by way of booklets written by Shanti Swaroop Baudh, Budh Sangh Premi, Shayar Devidas Gulde, S. K. Roshan, Bhikhu Pragya Deep, and others ${ }^{19}$. Dalit women have also been active agents in the production of these songs. Many poets and singers like Premlata, Shobha Baudh have published booklets of their songs.

\section{An Account of a Buddhist Singer from Uttar Pradesh}

The significance of devotional music in the form of Tathagata Buddha songs in U.P, which has a significant 20.7 per cent Dalit population $(\mathrm{MoSJE})^{20}$, can be understood in terms of its widespread popularity and circulation. This paper presents the case of a fairly popular Dalit singer, Pramita Gautam aka Dharmacharni Pragya Kirti, from Hapur in western U.P. Her voice is representative of many local voices for whom singing Bhimgeet and Tathagata Buddha songs has been an act of resistance and a means of empowerment. The ethnographic account of singers like Gautam's represents the microcosm through which the larger voices of resistances can be understood.

Gautam or Dharmacharni Pragya Kirti has undertaken a formal education and training in Buddhism under Triratna Buddha Mahasangha, ${ }^{21}$ Nagpur. She and her 
husband are members and activists of Bharatiya Boudh Mahasabha. Born and married in U.P., she discusses her commitment to Buddhism: 'Spreading the meaning and philosophy of Buddhism is the single goal of my life and I am willing to overcome all my hurdles in the path of spreading Buddhism.' Her speeches and songs, several of which she has herself composed, reflect the Buddhist philosophy and ideals of Babasaheb Ambedkar. For her songs are the medium through which she can 'express her reverence and commitment to Ambedkarism.'

She recalls that her inclination to Buddhist songs in terms of writing the lyrics and singing, developed particularly after she was conferred the title Dharamacharni at a seminar of the organization. Her style of singing is parody, which she considers is a powerful medium to connect with a larger audience. Showing the diary in which she has written her songs, she declares her plans to get them published with a sense of pride.

What has she gained as a Buddhist and as a singer? Buddhism, she says, has enabled a dignified position for her in society, and the songs gave her public recognition. 'Whenever I go to any of these cultural programmes, I do not book hotels. People are so much willing to host me at their residence. They know me because of my songs and have a deep sense of respect for what I am doing for the Dalit-Bahujan community', she says with a sense of gratitude.

Regarding her childhood, she recalls that she was interested in singing and would often accompany her father to Kabir Kirtan sabhas (gatherings), where she would recite from Bijak. It was towards her middle school that she got inclined towards Bhimgeet. Her inclination towards Babasaheb is an 'expression of reverence' she has for Dr Ambedkar, about whom she came to know through her father. 'My father told us, "Babasaheb is the one who has done everything for us, he has given us a respectful place in society." As a child, she often faced exclusionary practice by some teachers, which moved her further towards her commitment towards Ambedkar's mission. Further encouragement came when she sang her first song on Babasaheb Ambedkar in school and received appreciation from teachers of her community in particular. They further took her to different cultural platforms organized around Babasaheb's Mission. This further motivated her to sing on occasions like Babasaheb Jayanti (birth anniversary celebrations), which later became her passion.

When one particularly tries to understand the significance of these Buddhist songs in the lives of Dalit women, one finds that these have played an important role in reworking their identity and position in society. This change in the status of Dalit women singers has been particularly possible because of the Buddhist philosophy, which is based on the principles of equality, including that of gender, in society. Also, Buddhism does not have a stratified society based on caste; nor has it scriptures like Manusmriti that relegated women to a secondary position in society. The Dalit women who accrue to this Buddhist philosophy and are engaged in its cultural spread and promotion, have a dignified status in society.

Coming back to Pramita Gautam, she acknowledges a sense of solidarity nurtured with other Dalit women during the course of her singing career. The process of singing for her was has also been about capturing a public-sphere that she would have otherwise not gained access to due to the practice of 'purdah' (veil) that women in rural areas are usually supposed to practice. 


\section{Conclusion}

This paper has explored the history of songs of resistance (against the caste system) since the emergence of the Bhakti tradition until the emergence of Navayana tradition of Buddhism in post independent India. From medieval saints like Chokhmela, Eknath, Tukaram and Kabir, to the Dalit neo-Buddhists today; all have relied on the power of music and poetry to successfully voice their concern against the darkest practice of social exclusion in Hindu religion. Their songs of resistance against the graded inequality of the caste system find echo in the musical practices of Dalit Navayana Buddhists, who have drawn inspiration from the rich musical tradition of Bhakti movement to carve out a distinct cultural space for themselves.

This paper has studied the emergence of Tathagata Buddha Songs, Bhimgeet and similar musical productions in the Dalit-Bahujan community in Uttar Pradesh as a powerful tool to awaken social consciousness and cast off their dehumanizing caste identity under the Buddhist order.

Conversion to Buddhism has enabled the Dalit community to challenge the exploitative caste practice that has scriptural sanctions within Hindu tradition. These songs have worked differently for Dalits, especially women, as it has enabled them to question the authority of Manusmriti that gave them a demeaning position in society. These songs also have their cultural significance in that they have allowed the Dalit community to re-work and re-imagine their identity with a sense of dignity.

The musical renditions of Tathagata Buddha songs or, Bhimgeet may not be as popular as the 'Pop-Bhajans' of the 1980s. However, with the growing socio-cultural revolution these new-emerging forms are significantly creating a 'contested space' with the existing popular forms. This cultural contestation and resistance are reflected through the everyday lifeworld of prominent Dalit women singers like Pramita Gautam, Malti Rao, Shweta Shakya, Seema Azad, Taranum Baudh, Sanghamitra Gautam, Baudhmitra, among others who are both producers and consumers of such music. The microcosm of their lifeworld, in which these musical practices are situated somewhere, explains the meanings and significance of Tathagata Buddha songs for them.

\section{References}

Ambedkar, B.R. (1979). Revolution and Counter-Revolution. In Vasant Moon (ed.), Dr. Babasaheb Ambedkar: Writings and Speeches. Volume 3. New Delhi: Dr. Ambedkar Foundation.

Beighey, Catherine., and Unnithan, N. Prabha. (2006). Political Rap: The music of Oppositional Resistance. Sociological Focus. 39(2), 133-143.

Bradley, Tamsin and Zara Bhatewara. (2013). The place of 'practical spirtuality' in the lives of Dalit Buddhist in Pune. In Cosimo Zene. (ed.), The political philosophies of Antonio Gramsci and B.R.Ambedkar. New York: Routledge.

Dhere, Ramchandra Chintaman. (2011). Rise of a folk god: Vitthal of Pandharpur. Oxford: Oxford University Press.

Firth, Simon. (2007). Taking popular music seriously: selected essays. England: Ashgate Publishing Limited.

Friedman, Jonathan C. (2013). The Routledge History of songs of social protest in popular Music. New York: Routledge. 
Hawley, John Stratton. (2015). A storm of songs: India and the idea of the Bhakti Movement. Cambridge, Mass.: Harvard University Press.

Hess, Linda. (1983). The cow is sucking at the calf's teat: Kabir's upside-down language. History of Religions, 22(4), 313-337.

Hooks, Bell (1995). Art on my mind: visual politics. New York: New Press.

Jassal, Smita Tiwari. (2012). Unearthing gender: folk songs of north India. Durham: Duke University Press.

Joshi, Lal Mani. (1969). Brahmanism, Buddhism and Hinduism. New Delhi: Critical Quest.

Karwe, Irawati. (1988). Boy-Friend: An Essay. In Eleanor Zelliot and Maxine Bernsten (Eds.), The experience of Hinduism. Delhi: Sri Satguru publications.

Manuel, Peter. (2001). Cassette culture: popular music and technology in North India. New Delhi: Oxford University Press.

Omvedt, Gail. (2003). Buddhism in India: challenging Brahmanism and caste. New Delhi: Sage Publication.

Sindhwani, Navin (2011, Nov 30). What is Madhur Bhakti? The Speaking Tree, Retrieved from https://www.speakingtree.in/blog/what-is-madhur-bhakti

Schempp, Maren Bellwinkel. (2007). From Bhakti to Buddhism: Ravidas and Ambedkar. Economic and Political Weekly. 42(23), 2177-2183.

Tartakov, Gary Michael.(Ed). (2012). Dalit art and visual imagery. New Delhi: Oxford University Press.

Wankhade, Harish. (2008). The Political and Social in the Dalit Movement Today. Economic and Political Weekly. 43(6): 50-57.

Zelliot, Eleanor. (1980). Chokhamela and Eknath: Two Bhakti Modes of Legitimacy for Modern Change. Journal of Asian and African Studies. 15, 136-156.

\section{Endnotes}

1 Tathagata Buddha songs, used in this paper, refer to a set of musical practices that are centered around preaching, life, and philosophy of Tathagata or Gautam Buddha.

2 Dr. B. R. Ambedkar converted to Buddhism on October 14, 1956 along with his 3,65,000 followers in Deekshabhoomi, Nagpur. Eventually, Buddhism was embraced within Dalit communities at different moments in history. The rise of new anti-caste movement in the1970s and 1980s saw the conversion to Buddhism also among OBCs and some upper caste intellectuals (Omvedt, 2003, p. 266). Some of these names included Rahul Sankrityanan, Periyar, Lalai Singh, Chandrika Prasad Jigyasu, among others.

3 Dr. Ambedkar considered the emergence of Buddhism as 'a greatest blow to Brahamanism' (BWAS, Vol.3, p. 268). It was 'emancipating' because it loosened the Brahmin stronghold and control over state and religion. Thus, the sense of emancipation within Buddhism was rooted from the very beginning, as a counter-revolution to hegemonic structures established by Brahmanism.

4 Bhimgeet is a generic term used for musical songs and practices dedicated to Dr. B.R.Ambedkar and other Dalit-Bahujan leaders who have dedicated their lives for the cause of Dalit-Bahujan social emancipation.

5 See https://www.youtube.com/watch?v=i9fDCRJRpK4 and https:/www.youtube.com/ watch?v=pjazd35FhR4 accessed on September17, 2020.

6 Navayana Buddhism is a new form of Buddhism, taken up particularly by Dr. Ambedkar during his conversion. Omvedt (2003) argues that Navayana Buddhism was the 'revival' of Buddhism particularly towards the twentieth century. She has argued that Ambedkar's mass conversion was a 'Buddhist Renaissance' which was an assertion of reclaiming Dalit 
dignity. Thus, a sense of social emancipation was deeply embedded in the emergence of Navayana Buddhism. Tartakov (2012) hasdiscussed the uniqueness of Navayana Buddhism in terms of its representation in popular art, imagery, and its public visibility. He has argued that symbolic meanings around Navayana Buddhism are drawn from the everyday lived reality of Dalit lives. It is very much unlike other religious practices were rules of sacred and profane are followed.

7 The term 'Bhakti' in Bhakti tradition is also contested. Hawley (2015) has argued that the very idea of 'Bhakti movement' was formulated only in the twentieth century and it was largely influenced with the existing wave of nationalism. He argues that there was no single strand of 'Bhakti' as was popularly constructed rather each of the so called 'Bhakti tradition' had its unique history.

8 Vithoba of Pandharpur, is discussed in Dhere's writings as a folk god who deified in the city of Pandharpur, Maharashtra. He is also called Lord Vitthal, a form of Lord Vishnu or Krishna. The musical tradition of 'Abhangavani' is dedicated to Vitthal of Pandharpur. In contemporary times some of the popular tracks of Vitthal'sAbhangaare Gyanba Tukaram, Pandharpuras Yave Re, Yei Ho Vithale etc. See https://www.youtube.com/watch?v=AQ XZEoTmkgaccessed on September 17, 2020

9 Devotion to the Lord is considered to have four stages: Dasya(servitude), sakhya (friendly), Vatsalya (paternal) and Madhur (sweet). Madhur is the ultimate sweet relationship. For details see Sindhwani(2011)

10 Warkari movement is a religious movement in Maharashtra state within the Bhakti tradition associated with the devotees of Vitthala or Vithoba.

11 Dhere (2011) has argued that many of the musical practices, before they became popular, were sung in Madha regions (Solapur district) of Maharashtra.

12 Fifteenth century saint in Bengal.

13 Kabir was a fifteenth century Bhakti saint from the Julaha (weaver) community in Uttar Pradesh.

14 "To Minister to the Valley" address Feb 23, 1968. p. 21. King Papers.

15 Braj Lal Joshi says Tathagata means 'one who has arrived (Agata) at the timeless Nibbana in the same way (Tatha) just as the Enlightened Ones of former ages (pubbakehisammasambuddhehi) had attained to it.' (Joshi, 1969, p. 65).

16 Aarti refers to the prayer offered to God in a rhythmic pattern.

17 Singer: Shweta Shakya https://www.youtube.com/ watch? $\mathrm{v}=$ GV5Vic457i4\&list $=$ RDGxkGsZcSYqc\&index $=2$

18 Shanti Swaroop Baudh was the key figure in the establishment of Youth for Buddhist India. He was associated with Ambedkarite movement particularly in North India. It aimed to promote youth and give them platform to express their art and culture. Along with Hari Bharti, the mission of Youth for Buddhist India was 'to make an institution dedicated to make India Buddhist'. The platform witnessed art forms and musical performances dedicated to Babasaheb and Tathagata Buddha. See https://www.youtube.com/watch?v=eQeQt cYuMg\&t $=1599$ s access dated $17^{\text {th }}$ September, 2020 .

19 The booklets were written with a sense creating a sense of awareness of what Buddhism is meant and the reason one needs to embrace it. For instance, in one of the popular booklets Adivansh Katha by Dr. Angane Lal, discusses different myths that have belittled Dalit figures.

20 Union (Federal) Ministry of Social Justice and Empowerment, New Delhi.

21 A socio religious organization that preaches the philosophy of Buddha and his life. It also confers titles like Dharmachari, Bhante, Anagami, etc. 